Metadata of the chapter that will be visualized online

\begin{tabular}{|c|c|c|}
\hline Chapter Title & \multicolumn{2}{|c|}{ Ancient Human Bone Microstructure Case Studies from Medieval England } \\
\hline Copyright Year & \multicolumn{2}{|l|}{2019} \\
\hline Copyright Holder & \multicolumn{2}{|l|}{ Springer Nature Singapore Pte Ltd. } \\
\hline \multirow[t]{8}{*}{ Author } & Family Name & Walker \\
\hline & Particle & \\
\hline & Given Name & Meg M. \\
\hline & Suffix & \\
\hline & Division & \\
\hline & Organization/University & $\begin{array}{l}\text { School of Archaeology and } \\
\text { Anthropology, Australian National } \\
\text { University }\end{array}$ \\
\hline & Address & Canberra, ACT, Australia \\
\hline & Email & Meg.Walker@anu.edu.au \\
\hline \multirow[t]{7}{*}{ Author } & Family Name & Street \\
\hline & Particle & \\
\hline & Given Name & Emma M. \\
\hline & Suffix & \\
\hline & Division & \\
\hline & Organization/University & $\begin{array}{l}\text { School of Anthropology and } \\
\text { Conservation, University of Kent }\end{array}$ \\
\hline & Address & Canterbury, UK \\
\hline \multirow[t]{8}{*}{ Author } & Family Name & Pitfield \\
\hline & Particle & \\
\hline & Given Name & Rosie \\
\hline & Suffix & \\
\hline & Division & \\
\hline & Organization/University & $\begin{array}{l}\text { School of Anthropology and } \\
\text { Conservation, University of Kent }\end{array}$ \\
\hline & Address & Canterbury, UK \\
\hline & Email & R.J.Pitfield@kent.ac.uk \\
\hline \multirow[t]{5}{*}{ Corresponding Author } & Family Name & Miszkiewicz \\
\hline & Particle & \\
\hline & Given Name & Justyna J. \\
\hline & Suffix & \\
\hline & Division & \\
\hline
\end{tabular}




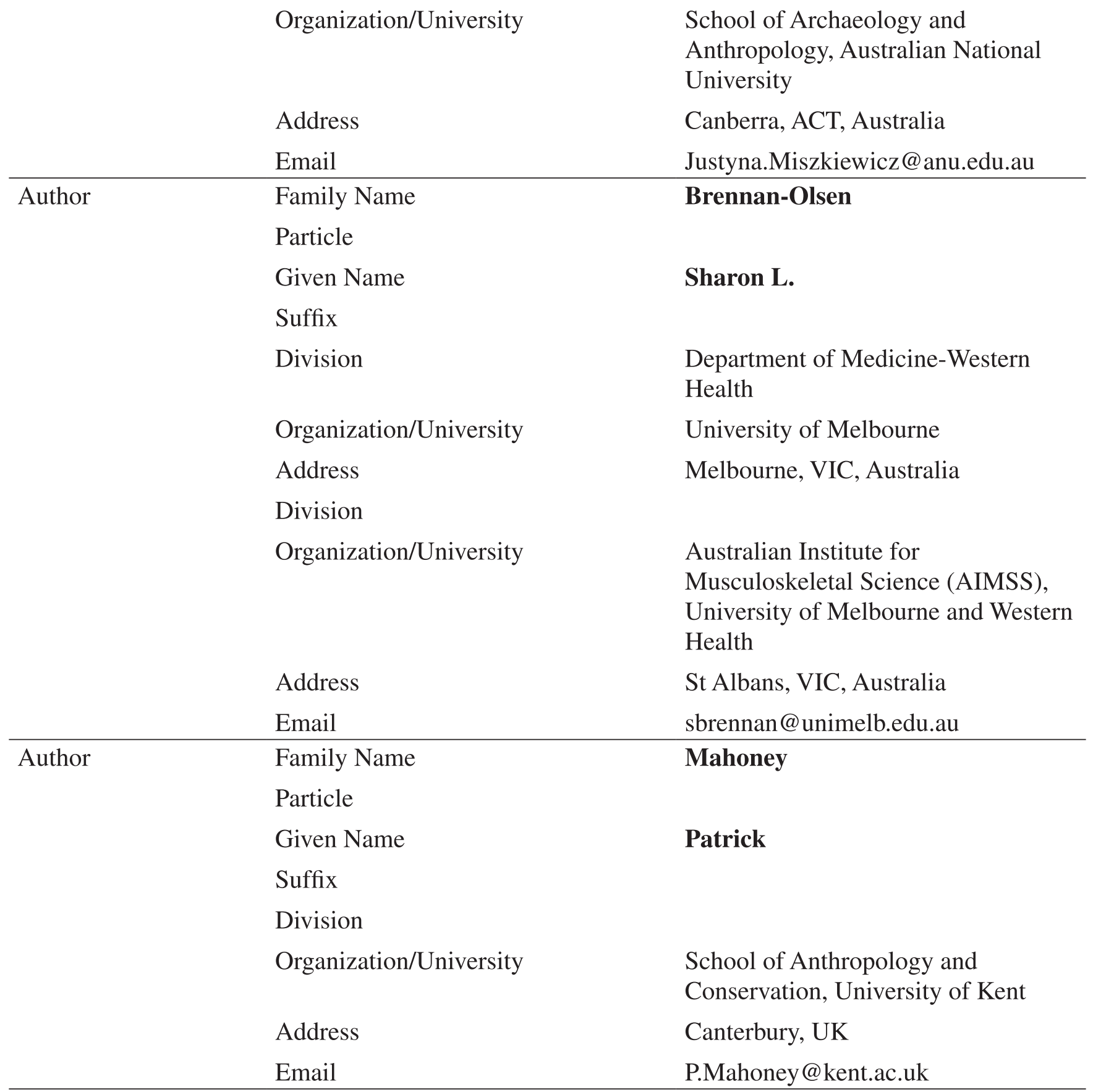


This chapter discusses two case studies using limb bone microstructure samples from a medieval (eleventh to sixteenth centuries) English skeletal collection in Canterbury. The site represents low and high socio-economic status (SES) groups. Firstly, the effect of SES on skeletal growth is investigated by combining dental indicators of childhood physiological stress and products of bone remodelling in 17 adults. Linear enamel hypoplasia (LEH) is used as a proxy for childhood ill health, and femur mid-shaft osteon population density (OPD) represents adult bone density. A statistically significant and strongly positive $(r=0.929, p=0.003)$ correlation between LEH and OPD was achieved in the high SES group only. We propose a preliminary medieval human skeletal growth model suggesting that individuals of higher SES are more likely to develop higher adult bone density despite their experiences of developmental disturbances in early ontogeny. Secondly, we use samples from the same skeletal collection to investigate the relationship between histomorphometric variability and cortical bone dimensions. The entire cross-section of the mid-shaft radius was examined in seven age-matched individuals. Significant negative correlations were found between OPD and the area and width of the cortical cross-section. Osteon area was significantly and positively correlated with cortical area. Results not only suggest that cortical bone size must be considered when evaluating histomorphometry but also extends current understanding of the ways in which Haversian systems develop. This chapter demonstrates the applicability of medieval human skeletal samples in furthering our current investigations into bone health and understanding the effects of lifestyle on skeletal growth.

Keywords (separated

Medieval skeletons - Linear enamel hypoplasia - Osteons - Bone remodelling by “ - ") - Histology - Femur - Radius 


\title{
Ancient Human Bone Microstructure Case Studies from Medieval England
}

\author{
Meg M. Walker, Emma M. Street, Rosie Pitfield, 3 \\ Justyna J. Miszkiewicz, Sharon L. Brennan-Olsen, 4 \\ and Patrick Mahoney
}

The reconstruction of human health in past populations can be successfully undertaken by analysing their surviving skeletal remains that derive from archaeological and historical contexts [1]. Outside of standard gross anatomical examination techniques that include recording the morphology and morphometry of different skeletal parts (see Chap. 2), mapping bone histological variation can contribute a more in-depth understanding of skeletal metabolic activity in past humans [2,3]. While ancient samples cannot be studied using dynamic or experimental bone histology, multiple studies have shown that, preservation permitting, static histology can successfully yield data about cortical bone density and its geometric properties [2-5]. Many different research themes of past human bone histology have been covered to date, including ageing [6], sex-specific division of labour [7], lifestyle [8] and osteoporosis [9]. However, little research has been done using samples that derive from

M. M. Walker · J. J. Miszkiewicz ( $\triangle)$

School of Archaeology and Anthropology, Australian National University,

Canberra, ACT, Australia

e-mail: Meg.Walker@anu.edu.au; Justyna.Miszkiewicz@ anu.edu.au

E. M. Street · R. Pitfield · P. Mahoney

School of Anthropology and Conservation, University of Kent, Canterbury, UK

e-mail: rjp41@kent.ac.uk; P.Mahoney@kent.ac.uk

\section{S. L. Brennan-Olsen}

Department of Medicine-Western Health, University of Melbourne,

Melbourne, VIC, Australia

Australian Institute for Musculoskeletal Science (AIMSS),

University of Melbourne and Western Health, St Albans, VIC, Australia

e-mail: sbrennan@unimelb.edu.au 
distinct socio-economic status (SES) groupings. In 2016 [3], two of our team reported the first ever large sample-based femoral bone microstructural patterns comparing low and high SES medieval English groups of adults (also see Chap. 2). We showed that low SES skeletons of adult males and females developed poorer bone health when compared to higher SES individuals. In an earlier 2012 study [10], Miszkiewicz reported differences between the low and high SES groups in their dental health and associated longevity. It was inferred that more prevalent childhood physiological disruption events and higher mortality may have characterised lower SES medieval individuals. As bone and dental enamel tissues respond to external and internal biological and environmental factors [11-14], an analysis of their association can elucidate how and if adult bone quality and quantity accounts for early ontogenetic developmental disturbances. This is the aim of the first part of this chapter.

In the second part of this chapter, we report on the relationships between cortical bone dimensions and histomorphometry of the medieval human radius. Bone histomorphometry can be influenced by age [6], sex [7], lifestyle [8] and pathology [9], but the potential links between bone size and histomorphometry have received less attention in the literature. Previous studies have reported correlations between the size of femoral cortical bone and the size and frequency of osteons [15]. The aim of the second part of this chapter is to examine the potential link between cortical dimensions of the medieval human radius and the underlying histology.

In both cases, we use samples ${ }^{1}$ taken from a large skeletal St. Gregory's Priory and associated cemetery collection dated to eleventh to sixteenth centuries, curated at the University of Kent (Canterbury, UK) [16, 17]. This is a well-preserved collection of medieval human skeletons that has been studied over the past few decades revealing their general health and disease $[10,16,18]$, as well as, more recently, bone histological variation during ontogeny [4], basics of adult bone biology and biomechanics [15, 19], lifestyles [3] and human dental and bone biorhythms [20, 21]. The basic biological affinities of each individual in the collection are estimated following standard anthropological methods that determine biological sex and ageat-death based on a series of pelvic, cranial, dental and postcranial anatomical characteristics [22].

As supported by archaeological and historical records outlined below, there is evidence that this site was split into two distinct regions of burial used for low (i.e., peasants buried in the associated cemetery) and high SES (i.e., the wealthy and clergy members of the society buried in the Priory) [23, 24]. Three key lines of evidence for this SES divide can be identified. Firstly, the basic demographic distribution of the recovered skeletons indicates that the Priory was designated both for

\footnotetext{
${ }^{1}$ Appropriate ethical guidelines and codes of practice for the analysis of human skeletal remains from archaeological contexts were followed, including the code of ethics of the American Association of Physical Anthropologists (2003), the British Association of Biological Anthropology and Osteoarchaeology code of practice and Mays S, Elders J, Humphrey L, White W, Marshall P. Science and the dead: guidelines for the destructive sampling of archaeological human remains for scientific analysis. Advisory Panel on the Archaeology of Burials in Britain, English Heritage; 2013.
} 
monastic and secular individuals, with the latter securing high SES burial through donations [17, 24]. An excavation of 21 subadults and a number of female skeletons at the Priory, alongside an overwhelming presence of male skeletons [24], confirms a combined ecclesiastical and secular high SES community. Several excavated graves were located inside the Priory, with male skeletons unearthed in the Priory's resonance chambers and the chapter house [17]. Initial archaeological reports [24] hinted the cemetery skeletons represented a population with high mortality at a young age, which was subsequently confirmed [10] with lower average age-at-death estimates in the cemetery (39.8 years) when compared to the Priory (44.1 years). Secondly, oral health assessment indicated high prevalence of dental caries in the Priory samples [17] suggesting an increased carbohydrate consumption, also associated with medieval cloisters in other parts of the UK [25]. Thirdly, elaborate grave goods uncovered in the Priory point to high social standing of those buried in the Priory. For example, one adult male was excavated with a chalice and a goldembroidered garment, with Hicks and Hicks [17] speculating this may have been the skeleton of Prior Alured (1146-1470 AD). The difference in lifestyles and daily occupations between low and high SES in the medieval English period is well established [26] (also see Chaps. 1 and 2 in this volume).

\subsection{Medieval Individuals from High SES Backgrounds 75 Achieve Higher Bone Density Despite Experiences 76 of Childhood Developmental Disruption 77}

Based on prior observations, in past and living populations, that low SES has an 78 adverse effect on multiple human (bone) health variables (see Chap. 1 for theoreti- 79 cal background and Parts 2 and 3 in this volume) [3, 10, 27, 28], we hypothesised 80 that being born into, and growing up in a high medieval SES context, should have a 81 positive effect on adult bone density. We test this hypothesis by studying proxy 82 variables for adult bone density from the human femur and dental indicators of 83 childhood non-specific physiological disruption in $n=17$ adult individuals from 84 medieval Canterbury for whom these matched data are available. 85

\subsubsection{Brief Background}

Linear enamel hypoplasia (LEH) is a dental condition that manifests as a decrease in enamel density on the external surfaces of the teeth [29] (Fig. 3.1). It is thought that it occurs following a disruption to the formation of enamel during childhood while permanent teeth are developing [30]. Because enamel formation is a tightly controlled process, a temporary reduction in enamel thickness and shortened enamel prisms are a consequence of systemic or localised disturbance to its development [31]. It is impossible to reconstruct the exact aetiological factors underlying the formation of LEH in ancient human samples; thus LEH can be used as a permeant representation of non-specific childhood physiological "stress" [32]. This "stress" can take many forms of interpretation depending on 

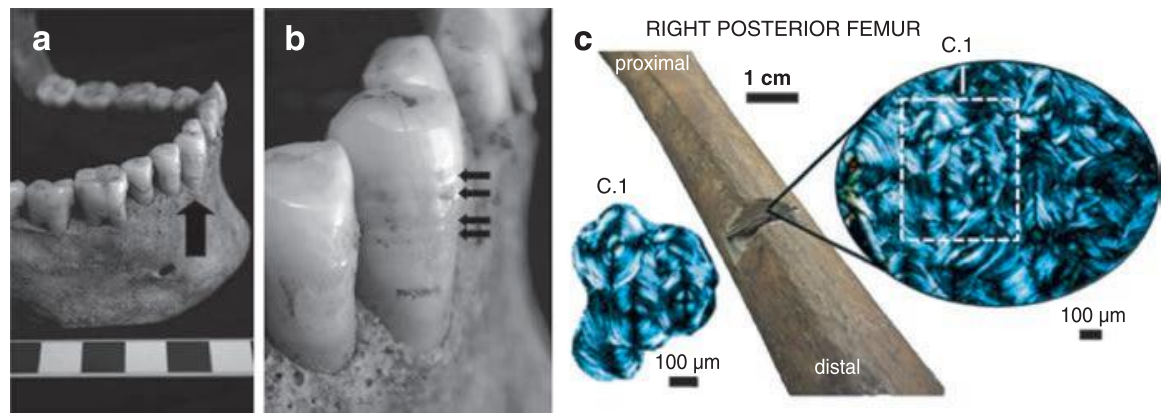

Fig. 3.1 Mandibular anterior dentition (a, b) and right posterior femur (c) from the Canterbury collection. Arrows in images $(\mathbf{a}, \mathbf{b})$ mark linear enamel hypoplastic lines expressed on the labial dental surface of a canine. These indicate several episodes of enamel development disruption during childhood. Image $C$ shows the histology sampling location previously reported in $[3,18,19]$ and associated histological appearance under linearly polarised light. The C.1 image gives an example of secondary osteons showing intact and fragmentary remnants of bone remodelling. Images $(\mathbf{a}, \mathbf{b})$ are reprinted with permissions from John Wiley and Sons [10]

the population context, but there is evidence that LEH can form in response to malnutrition [33], systemic illness and pathogens [11], weaning [34] and consumption of toxins [35]. The aetiology of LEH and some causal links made to lifestyle factors in anthropological research remain debated [35-38], but it is clear that studying LEH in adults indicates developmental disturbance recovery with the sufferer surviving a period or series of physiological disruption events [38]. As per the 2012 LEH study in medieval Canterbury [10], low SES adults show an average of 17.6 LEH lines when compared to 7.9 LEH lines in the high SES group. Not only do these data support the SES divide in this population, they also demonstrate that high SES individuals were not shielded from childhood physiological stress.

To assess the relationship between childhood developmental issues and adult bone health, we turn to secondary osteon population density (OPD) collected from femoral samples in this medieval population. As the bone is a living tissue that remodels through the processes of targeted and nontargeted remodelling [39], we can reconstruct basic bone density information by recording secondary products of bone remodelling from cortical bone histology [40]. The basic multicellular unit (BMU) of coupled osteoblasts and osteoclasts remodels bone by resorbing and depositing new tissue, either during an equilibrium or bone balance phase or in response to mechanical load, diet and disease [12]. As BMUs dig cortical "tunnels," they leave behind osteon structures composed of lamellae with a central Haversian canal that delivers blood supply to bone tissue (Fig. 3.1). The sum of osteons per area of examined section is a representation of the accumulated osteons and is informative of bone remodelling rates experience at a given bone site [40]. 
Table 3.1 Descriptive linear enamel hypoplasia (LEH) [10] and osteon population density [3] data subdivided by SES, sex and age-at-death groupings in the whole sample

\begin{tabular}{|c|c|c|c|c|c|c|c|c|}
\hline SES & Sex & Age-at-death & $\begin{array}{l}\text { Dental and } \\
\text { bone data }\end{array}$ & $N$ & Min. & Max. & Mean & $\mathrm{SD}$ \\
\hline \multirow{6}{*}{$\begin{array}{l}\text { Low (most } \\
\text { disadvantaged) }\end{array}$} & \multirow[t]{4}{*}{ Female } & \multirow[t]{2}{*}{ Young } & LEH & 1 & 2.00 & 2.00 & 2.00 & - \\
\hline & & & OPD & 1 & 17.86 & 17.86 & 17.86 & - \\
\hline & & \multirow[t]{2}{*}{ Middle-aged } & LEH & 1 & 6.00 & 6.00 & 6.00 & - \\
\hline & & & OPD & 1 & 15.41 & 15.41 & 15.41 & - \\
\hline & \multirow[t]{2}{*}{ Male } & \multirow[t]{2}{*}{ Middle-aged } & LEH & 8 & 6.00 & 32.00 & 16.75 & 10.14 \\
\hline & & & OPD & 8 & 14.62 & 22.84 & 17.91 & 2.43 \\
\hline \multirow[t]{7}{*}{ High } & \multirow[t]{4}{*}{ Female } & \multirow[t]{2}{*}{ Young } & LEH & 1 & 11.00 & 11.00 & 11.00 & - \\
\hline & & & OPD & 1 & 26.79 & 26.79 & 26.79 & - \\
\hline & & \multirow[t]{2}{*}{ Middle-aged } & LEH & 2 & 4.00 & 6.00 & 5.00 & 1.41 \\
\hline & & & OPD & 2 & 17.63 & 18.86 & 18.25 & 0.87 \\
\hline & \multirow[t]{3}{*}{ Female } & \multirow[t]{3}{*}{ Middle-aged } & LEH & 4 & 2.00 & 30.00 & 12.75 & 12.04 \\
\hline & & & OPD & 4 & 14.73 & 26.34 & 21.45 & 4.88 \\
\hline & & & Total $n$ & 17 & & & & \\
\hline
\end{tabular}

Sex and age-at-death were estimated following standard anthropological procedures [22]

t1.1 $\mathrm{t} 1.2$ $\mathrm{t} 1.3$ t1. 4 t1. 5 $\mathrm{t} 1.6$ t1. 7 t1. 8 t1.9 $\mathrm{t} 1.10$ $\mathrm{t} 1.11$ t1.12 $\mathrm{t} 1.13$ $\mathrm{t} 1.14$ t1.15 t1.16 $\mathrm{t} 1.17$ $\mathrm{t} 1.18$

\subsubsection{Sample and Methods}

We were able to match and extract previously collected and published LEH and 123 OPD data for a set of $n=10$ low SES (cemetery) and $n=7$ high SES (Priory) adults 124 $[3,10]$ (Table 3.1). The raw LEH data [10] derive from unworn anterior maxillary 125 and mandibular permanent incisors and canines and represent total frequencies. 126 These were collected using the "field method" approach, which scans labial tooth 127 surfaces for macroscopic presence of LEH [41]. The OPD data are from subperios- 128 teal posterior cortical mid-shaft femur regions collected from thin sections as 129 reported in $[3,15,19]$. The OPD values were calculated as the sum of intact osteon 130 (N.On) and fragmentary osteon (N.On.Fg) densities (Fig. 3.1) per section area 131 $\left(2.24 \mathrm{~mm}^{2}\right)$ from a maximum of six regions of interest (ROIs). Given the limited 132 sample size, we correlated individual LEH and OPD data points using non- 133 parametric Spearman's Rho tests.

\subsubsection{Results}

A highly significant, strongly positive correlation was found between OPD and 136 LEH in the high SES group only (Rho $=0.929, p=0.003, n=7$ ) (Fig. 3.2). When 137 considering the low SES group, no relationship as such was identified (Rho $=0.227, \quad 138$ $p=0.528, n=10$ ). For the former correlation, it was clear that there was an associ- 139 ated increase in OPD alongside LEH (Fig. 3.2), with individuals of more dental 140 disturbances also showing higher bone density. We pooled sexes within each SES 


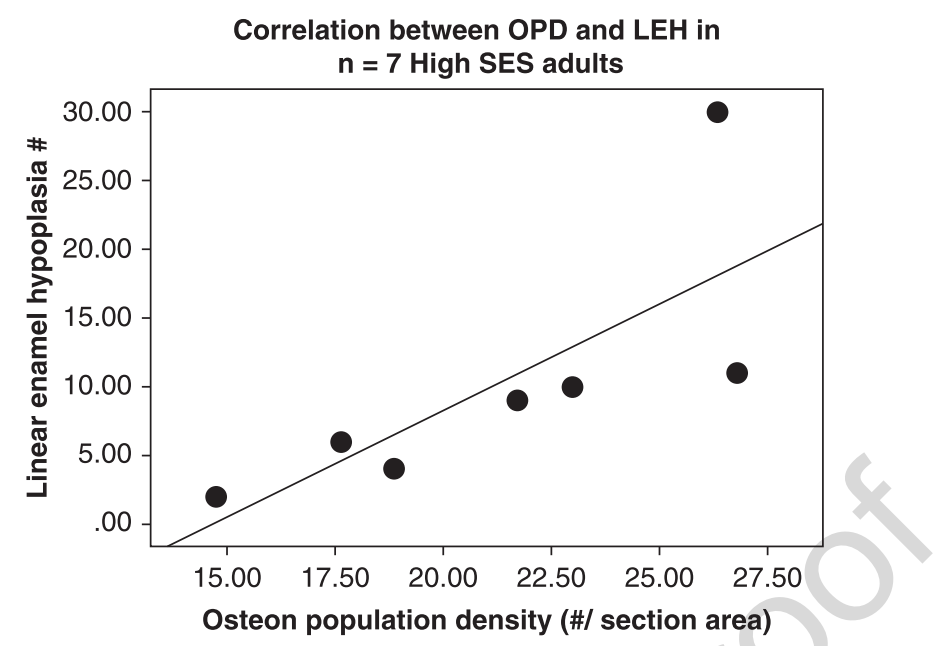

Fig. 3.2 A correlation between total linear enamel hypoplasia (LEH) frequencies of the anterior dentition and associated osteon population density (OPD) in seven individuals deriving from a high medieval SES group $(r=0.929, p=0.003)$

group for the above analyses due to the small sample size. Once males of both high and low SES were examined $(n=14)$, there was no effect of sex on $\operatorname{LEH}(\mathrm{Rho}=0.248$, $p=0.393)$.

\subsubsection{Discussion and Conclusions}

These preliminary results demonstrate that an increase in LEH is associated with an increase in OPD in individuals from high SES backgrounds. This may indicate that developmental disturbances that arise from physiological health issues in high SES children are accounted for by developing a robust or "stronger" skeleton in adulthood. The lack of significant relationships between LEH and OPD in the low SES group suggests that malnutrition and/or general physiological ill health leave a mark on the adult skeleton in the form of poor bone health. Our data support previous studies utilising this human sample where significant differences in mortality [10] and bone remodelling were observed [3], with the low SES individuals living less long and presenting with bone loss in adulthood. We propose a preliminary skeletal growth model within a medieval Canterbury SES context, whereby advantageous SES backgrounds may facilitate healthy bone accrual later in ontogeny (see further theory in Chap. 1).

Considering medieval historical records, skeletons recovered from the Priory would have included members of the clergy and lay wealthy noblemen who would have had access to good-quality nutrition, undertaken less physically demanding occupations and led lifestyles within more secure environments [26, 42]. On the contrary, individuals buried in the associated cemetery represent the sick and poor 
locals of medieval Canterbury [43], who would have fed on simple and less nutri- 164 tious diets, undertaken more strenuous occupations and not been shielded from 165 daily stress and insecurities [44]. Of course, human behaviour is complex, and so it 166 is plausible that a mosaic of dietary and lifestyle factors played a role in skeletal 167 growth within each SES group. For example, Polish peasants (eleventh and twelfth 168 century Giecz) are reported to have consumed an animal meat-rich diet [45] chal- 169 lenging the idea of simple dietary regimes in lower medieval European classes. The 170 multiple LEH events recorded in the Priory samples in our study agree with previ- 171 ous research where higher SES groups are affected by developmental disturbances 172 [46]. As much as our results support the notion that higher SES skeletons grow 173 higher density bone in adulthood, they cannot strictly imply that people of privi- 174 leged backgrounds were shielded of infections or other disease. One must consider 175 poor sanitation and hygiene, overcrowding and limited health care in the medieval 176 past, which would have made the spread of infections and epidemics easier [47]. 177

Bone biology principles suggest that our results may demonstrate an example of 178 a skeletal growth catch up in the high SES group. Developing bone adapts to periods 179 of growth disruption and has a well-functioning recovery system in place $[48,49] .180$ However, where children develop in contexts of poor prenatal care and nutrition, 181 early weaning, and high loads of pathogens, skeletal growth is compromised, and 182 height can become stunted [50]. This indicates that the early conditioning of bone 183 quality and quantity in our low SES group did not lead to bone density catch up in 184 adulthood. We acknowledge the difficulty in extrapolating individual lifestyle fac- 185 tors underlying our results, alongside limitations that include genetically and 186 mechanically driven bone functional adaptation [12], LEH accrual rate and small 187 sample size. However, these preliminary results invite future research investigating 188 our hypothesis using medieval juvenile skeletal data.

\subsection{Histomorphometry of Cortical Bone in the Human} Radius

Many intrinsic and extrinsic factors can influence cortical bone histomorphometry including age, sex, body weight, biomechanical loading, economic and nutritional status, as well as pathology [3,51-58]. This study examines the relationship between cortical bone dimensions and the histomorphometry of the human radius - the bone that is commonly injured in modern osteoporotic patients [59]. Dimensions from the entire cross-section of seven adult radii were assessed against osteon population density and the size of osteons and Haversian canals to reveal insights into medieval bone growth.

\subsubsection{Brief Background}

Few studies have evaluated the histomorphometry of the entire cross-section of a 201 bone. Gocha and Agnew [60] examined OPD across the mid-shaft of the femur. Not 202 
only did the authors find a difference between the periosteal, mid-cortex and endosteal thirds, they also discovered a lack of consistency in OPD distribution [60]. Different patterns were observed across almost every ROI possibly in relation to levels and types of strain. Other studies have demonstrated relationships between femoral cortical size and histomorphometric variation $[3,19]$. Two of our team [15] measured cortical thickness (Ct.Wi) of the mid-shaft of the femur and revealed a significant positive correlation between Ct.Wi and OPD. A significant negative correlation was found between Ct.Wi and osteon area (On.Ar), Haversian canal area (H.Ar) and Haversian canal diameter (H.Dm) [15]. This indicated that changes in bone remodelling and the resulting secondary osteons may be linked to femoral cortical width and robusticity [15]. The aim here is to assess the entire cross-section of the mid-shaft of the radius - by dividing it into 32 ROIs - to determine if there is a structural relationship between cortical bone size and histomorphometric variation in the mid-shaft of the human radius. These relationships will be sought in the periosteal, mid-cortex and endosteal regions.

\subsubsection{Sample and Methods}

The bone sections were from $n=7$ age-matched individuals deriving from the aforementioned medieval eleventh to sixteenth centuries Canterbury collection [2]. Ageat-death and sex were estimated following standard methods [22]. Only one cross-section was incomplete, with the posterior and posterolateral sections missing, removing a potential eight ROIs. However, the rest of the section was intact and clear under the microscope meaning that 24 ROIs were still usable, as such this fragmented sample was included. This meant that while samples were obtained from $n=7$ individuals, statistical tests varied in sample size when subdividing by area of the cross-section $(n=54)$ (Table 3.2); examining all ROIs using Ct.Ar had a much larger sample size $(n=222)$, which varied only slightly when examining Ct.Wi $(n=216)$ as average width was not measured for the entire cross-sections, only smaller ROIs.

The samples came from individuals of the same age range (25-35 years old, $n=4$ females, $n=3$ males) ensuring that age, which has a much more significant influence on bone histomorphometry than sex [54], was accounted for in analyses. These bone samples had been prepared for a previous study [61] using standard histological methods. Thick sections were removed from the mid-shaft of the radius, embedded in resin and using a precision saw were further reduced to $0.3 \pm 0.1 \mathrm{~cm}$. The sections were then mounted onto glass slides and further grounded to a final thickness of 50-100 $\mu \mathrm{m}$ and then polished to ensure that the histological features were clearly visible under the microscope $[4,15,19,61]$.

Images of the whole cross-sectional area of each radius were captured at $10 \times$ magnification using a BX53 Olympus microscope and associated camera. The background of each image was removed using Affinity Photo software (v 1.6.5) to ensure that measurements focused only on the dimensions of the radius. The image was compared to the original slide and the radius from which it had been taken to 
Table 3.2 Descriptive statistics values of which represent mean and SD for averages of variables measured as subdivided into areas of the radius cross-section

\begin{tabular}{|c|c|c|c|c|}
\hline \multirow[b]{2}{*}{ Variable measured } & Octants & $\begin{array}{l}\text { Endosteal } \\
\text { sections }\end{array}$ & $\begin{array}{l}\text { Mid-cortex } \\
\text { sections }\end{array}$ & $\begin{array}{l}\text { Periosteal } \\
\text { sections }\end{array}$ \\
\hline & \multicolumn{4}{|l|}{$(n=54)$} \\
\hline Cortical area (Ct.Ar) & $11.104(4.532)$ & $2.602(1.007)$ & $3.631(1.476)$ & $4.902(2.149)$ \\
\hline $\begin{array}{l}\text { Cortical width }(\mathrm{Ct} \text {. } \\
\text { Wi) }\end{array}$ & $3.187(1.174)$ & $1.062(0.391)$ & $1.062(0.391)$ & $1.062(0.391)$ \\
\hline $\begin{array}{l}\text { Intact osteon density } \\
\text { (N.On) }\end{array}$ & $10.501(2.113)$ & $7.220(2.662)$ & $10.740(2.699)$ & $12.129(3.039)$ \\
\hline $\begin{array}{l}\text { Fragmentary osteon } \\
\text { density (N.On.Fg) }\end{array}$ & $2.680(1.213)$ & $2.364(1.501)$ & $3.056(1.626)$ & $2.585(1.384)$ \\
\hline $\begin{array}{l}\text { Osteon population } \\
\text { density (OPD) }\end{array}$ & $13.181(2.913)$ & $9.583(3.644)$ & $13.796(3.778)$ & $14.714(3.837)$ \\
\hline Osteon area (On.Ar) & $\begin{array}{l}36969.934 \\
(7661.622)\end{array}$ & $\begin{array}{l}38595.49 \\
(13283.449)\end{array}$ & $\begin{array}{l}38154.881 \\
(10062.025)\end{array}$ & $\begin{array}{l}34597.839 \\
(11331.311)\end{array}$ \\
\hline $\begin{array}{l}\text { Osteon diameter } \\
(\text { On.Dm) }\end{array}$ & $\begin{array}{l}186.35 \\
(20.463)\end{array}$ & $\begin{array}{l}192.072 \\
(34.44)\end{array}$ & $190.826(25.452)$ & $\begin{array}{l}177.622 \\
(29.869)\end{array}$ \\
\hline Canal area (H.Ar) & $\begin{array}{l}2937.160 \\
(864.934)\end{array}$ & $\begin{array}{l}3565.179 \\
(2011.747)\end{array}$ & $\begin{array}{l}3137.497 \\
(1122.386)\end{array}$ & $\begin{array}{l}2417.98 \\
(834.573)\end{array}$ \\
\hline $\begin{array}{l}\text { Canal diameter }(\mathrm{H} . \\
\text { Dm) }\end{array}$ & $51.237(7.843)$ & $55.85(16.467)$ & $53.472(10.081)$ & $46.82(8.39)$ \\
\hline
\end{tabular}

ensure that directional labels were correctly assigned. The image was then rotated 245 so that the medial and lateral regions were situated horizontally. This made it easier 246 to methodically number each image, allowing the ROIs of each section to corre- 247 spond uniformly.

The moment-macro plugin (v 1.3) was used in ImageJ (v1.46) software to find and mark the exact centroid of the section [60]. An eight prong spoke axis was then overlaid onto the image using Affinity Photo software, with the marked centroid providing the central point. This divided the section into octants-medial, posteromedial, posterior, posterolateral, lateral, anterolateral, anterior and anteromedial. The eight regions were subdivided into three areas using the cellSens Standard software. These three represented the periosteal, mid-cortex and endosteal regions of each octant (Fig. 3.3). This was done by measuring the length of the bone along each spoke prong and dividing it into three. The same was done through the middle of the octant to ensure a more even split for the area of the thirds. The measurement through the centre of the octant also provided the measurement for the width of each ROI. This method was based on that implemented by Gocha and Agnew [60] in their evaluation of OPD through the cross-section of the femoral mid-shaft. Other projects have also used a similar methodology for cross-section division [62-66].

\subsubsection{Image Analysis}

Using cellSens Standard software, the total area and medullary area were measured first. The cortical area was calculated by subtracting the medullary area from the

\section{8}

249

250

251

252

253

254

255

256

257

258

259

260

261

262 


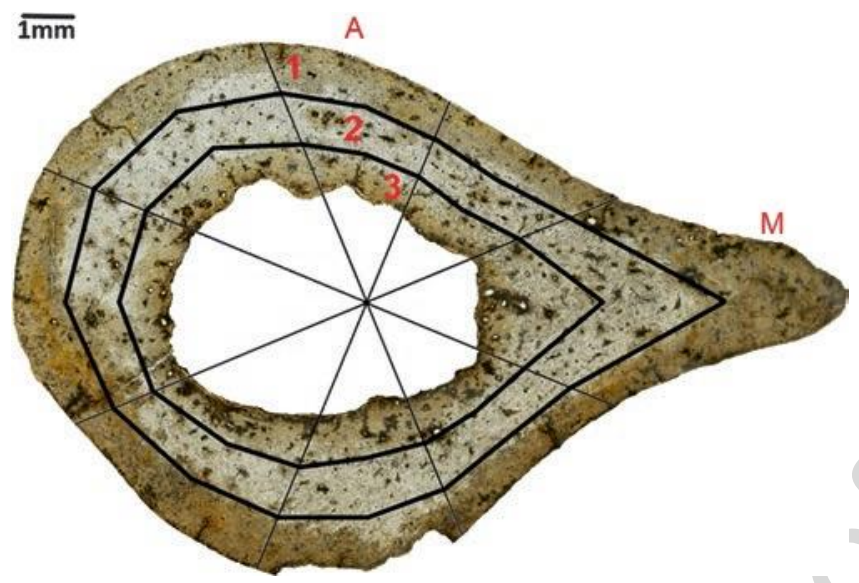

Fig. 3.3 The entire cross-section of a radius (A, anterior; $M$, medial) divided into sections, showing octants, and further subdivision into (1) periosteal, (2) mid-cortex and (3) endosteal regions

total area. The area and perimeter of each ROI was measured, including each octant and the three sections within. Second, the intact secondary osteons and osteon fragments were marked and counted to ascertain the OPD of each ROI. An osteon was considered a fragment if more than $10 \%$ of the Haversian canal had been remodelled by the development of a subsequent secondary osteon, as is consistent with previous studies $[4,67]$.

Following this, the following variables were measured or calculated:

1. OPD, number of intact secondary osteons and fragmented secondary osteons as defined by the above criteria divided by area of ROI

2. On.Ar, average osteon area measured in $\mu \mathrm{m}^{2}$ using the measurements taken of all viable osteons within the ROI, excluding those with unclear cement lines or irregular shape

3. H.Ar, average Haversian canal area measured in $\mu \mathrm{m}^{2}$ using the measurements taken of all viable canals within the ROI, excluding those with unclear outlines or irregular shape

4. On.Dm, average osteon diameter measured in $\mu \mathrm{m}^{2}$ by measuring the shortest diameter from edge to edge of all viable osteons within the ROI (Fig. 3.3)

5. H.Dm, average Haversian canal diameter measured in $\mu \mathrm{m}^{2}$ by measuring the shortest diameter from edge to edge of all viable canals within the ROI

All abbreviations used follow the standard nomenclature as reported by Dempster et al. [68].

\subsubsection{Statistical Analysis}

A total of 90 linear regressions were performed. This allowed for the relationship between the dimensions of the cortical bone and every histomorphometric variable 
Table 3.3 Results of linear regressions of different radius bone cross-section segments evaluating relationships between a series of histological and cortical measurements

\begin{tabular}{|c|c|c|c|c|c|c|c|}
\hline Variables & $\begin{array}{l}\text { Region of } \\
\text { interest }\end{array}$ & $N$ & Intercept & Slope & $R$ & $P$ & Residual \\
\hline \multirow[t]{5}{*}{ Ct.Ar and OPD } & All sections & 222 & 1.081 & 0.009 & 0.023 & 0.729 & 99.951 \\
\hline & Octants & 54 & 1.373 & -0.260 & -0.527 & 0.000 & 72.315 \\
\hline & Endosteal & 54 & 1.066 & -0.287 & -0.318 & 0.019 & 89.912 \\
\hline & Mid-cortex & 54 & 1.273 & -0.280 & -0.484 & 0.000 & 76.563 \\
\hline & Periosteal & 54 & 1.321 & -0.258 & -0.457 & 0.001 & 79.098 \\
\hline \multirow[t]{5}{*}{ Ct.Wi and OPD } & All sections & 216 & 1.094 & -0.066 & -0.123 & 0.071 & 98.481 \\
\hline & Octants & 54 & 1.263 & -0.319 & -0.553 & 0.000 & 69.451 \\
\hline & Endosteal & 54 & 0.956 & -0.160 & 0.168 & 0.225 & 97.193 \\
\hline & Mid-cortex & 54 & 1.126 & -0.334 & -0.494 & 0.000 & 75.521 \\
\hline & Periosteal & 54 & 1.153 & -0.424 & -0.583 & 0.000 & 66.015 \\
\hline \multirow[t]{5}{*}{ Ct.Ar and On.Ar } & All sections & 222 & 4.546 & 0.003 & 0.008 & 0.907 & 100 \\
\hline & Octants & 54 & 4.415 & 0.143 & 0.300 & 0.027 & 91.026 \\
\hline & Endosteal & 54 & 4.509 & 0.132 & 0.139 & 0.318 & 98.131 \\
\hline & Mid-cortex & 54 & 4.526 & 0.079 & 0.126 & 0.366 & 98.390 \\
\hline & Periosteal & 54 & 4.365 & 0.236 & 0.343 & 0.011 & 88.235 \\
\hline \multirow[t]{5}{*}{ Ct.Wi and On.Ar } & All sections & 216 & 4.541 & 0.089 & 0.182 & 0.007 & 96.702 \\
\hline & Octants & 54 & 4.459 & 0.211 & 0.379 & 0.005 & 85.641 \\
\hline & Endosteal & 54 & 4.560 & 0.190 & 0.188 & 0.173 & 96.495 \\
\hline & Mid-cortex & 54 & 4.567 & 0.137 & 0.187 & 0.177 & 96.486 \\
\hline & Periosteal & 54 & 4.518 & 0.303 & 0.342 & 0.011 & 88.337 \\
\hline \multirow{5}{*}{$\begin{array}{l}\text { Ct.Ar and On. } \\
\text { Dm }\end{array}$} & All sections & 222 & 2.265 & -0.001 & -0.004 & 0.955 & 100 \\
\hline & Octants & 54 & 2.182 & 0.085 & 0.328 & 0.016 & 88.696 \\
\hline & \begin{tabular}{|l|} 
Endosteal \\
\end{tabular} & 54 & 2.236 & 0.106 & 0.217 & 0.115 & 95.266 \\
\hline & Mid-cortex & 54 & 2.261 & 0.030 & 0.094 & 0.498 & 99.432 \\
\hline & Periosteal & 54 & 2.161 & 0.128 & 0.357 & 0.008 & 87.313 \\
\hline \multirow{5}{*}{$\begin{array}{l}\text { Ct.Wi and On. } \\
\text { Dm }\end{array}$} & All sections & 222 & 2.262 & 0.034 & 0.131 & 0.054 & 98.291 \\
\hline & Octants & 54 & 2.226 & 0.088 & 0.293 & 0.032 & 91.304 \\
\hline & Endosteal & 54 & 2.276 & 0.092 & 0.178 & 0.197 & 96.746 \\
\hline & Mid-cortex & 54 & 2.277 & 0.028 & 0.075 & 0.590 & 99.432 \\
\hline & Periosteal & 54 & 2.244 & 0.139 & 0.301 & 0.027 & 91.045 \\
\hline
\end{tabular}

t3.1

measured to be assessed using all ROIs grouped together and also subdivided to show the possible significance for each variable when examining the octants in isolation and each third (endosteal, mid-cortex and periosteal) separate from the other ROIs. Pearson's correlations were performed to identify correlation between the OPD and any other histomorphometric variables. This allowed further investigation into any potential relationships identified in the linear regressions by determining if they would be reflected in the histomorphometric variation and not just their relationship to the cortical bone. The level of significance for all analyses was set at $p \leq 0.05$. 

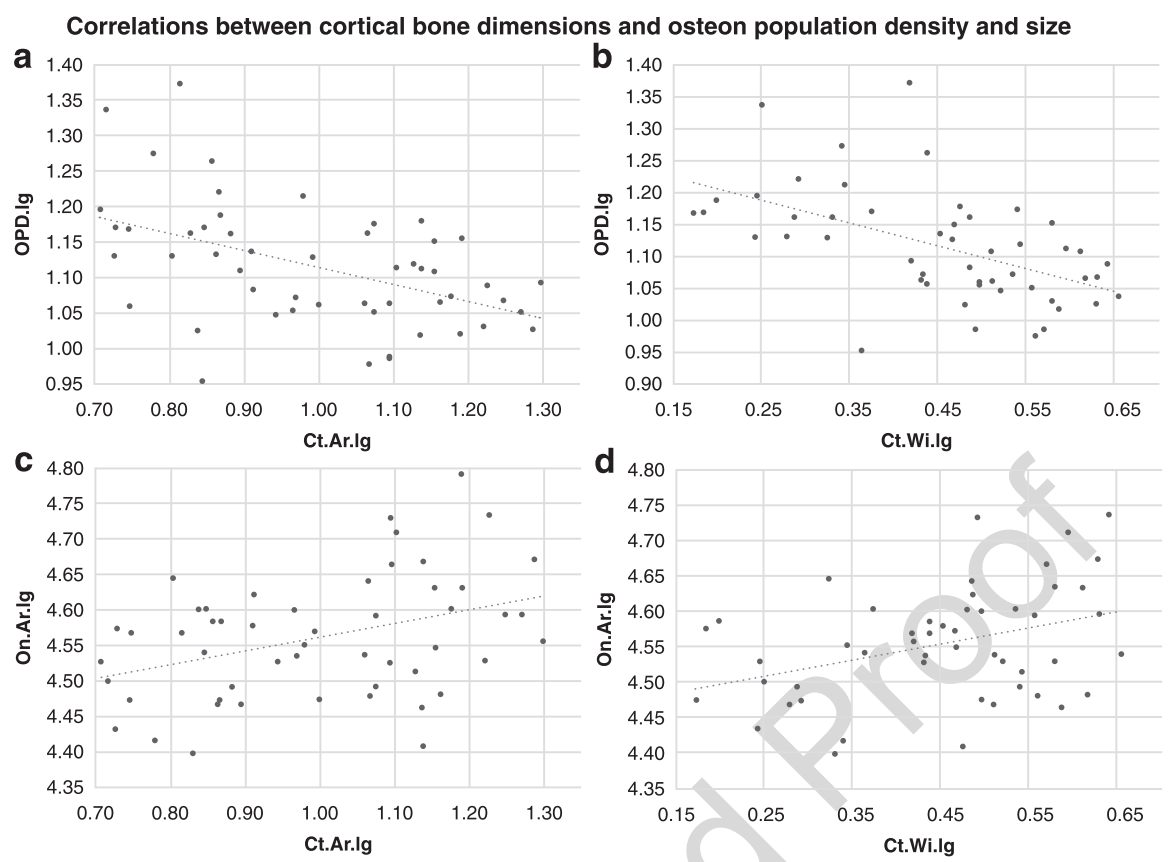

Fig. 3.4 Correlations of variables when evaluating the octants-(a) shows the negative correlation between osteon population density (OPD) and cortical area Ct.Ar, (b) shows the negative correlation between OPD and Ct.Wi, (c) shows the positive correlation between osteon area (On. $\mathrm{Ar})$ and Ct.Ar and (d) shows the positive correlation between On.Ar and cortical width (Ct.Wi)

\subsubsection{Results}

\subsubsection{Linear Regressions}

An increase in the size of cortical bone was linked to larger osteons but a decrease in their density (Table 3.3, Fig. 3.4). Significant negative correlations emerged between Ct.Ar and OPD in the octants $(p<0.000, r=-0.527)$, the endosteal sections $(p=0.019, r=-0.318)$, the mid-cortex sections $(p<0.000, r=-0.484)$ and the periosteal sections $(p=0.001, r=-0.457)$. Significant negative correlations also emerged between Ct.Wi and OPD in the octants $(p<0.000, r=-0.553)$, the midcortex sections $(p<0.000, r=-0.494)$ and the endosteal sections $(p=0.001$, $r=-0.424)$. In contrast, significant positive correlations were present between Ct.Ar and On.Ar in the octants $(p=0.027, r=0.300)$ and the periosteal sections $(p=0.011, r=0.343)$. Significant positive correlations occurred between Ct.Wi and On.Ar when testing all sections $(p=0.007, r=0.182)$, just octants $(p=0.005$, $r=0.379)$ and the periosteal sections $(p=0.011, r=0.342)$. The size of cortical bone was also positively related to On.Dm in the octants (Ct.Ar, $p=0.016$ and $r=0.328$; Ct.Wi, $p=0.032$ and $r=0.293$ ) and the endosteal sections (Ct.Ar, $p=0.008$ and $r=0.357$; Ct.Wi, $p=0.027$ and $r=0.301$ ). 


\subsubsection{Correlations}

Negative correlations were found between OPD and H.Ar $(p=0.004$ and $r=-0.196), \quad 308$ OPD and H.Dm ( $p=0.019$ and $r=-0.159)$ and OPD and On.Ar $(p=0.001$ and 309 $r=-0.215)$ and between OPD and On.Dm $(p=0.008$ and $r=-0.117)$.

\subsubsection{Discussion and Conclusions}

Results show negative correlations between the size of cortical bone and OPD and 312 a positive correlation between the dimensions of cortical bone and the size of 313 osteons. The results for the radii differ to those previously presented for femur [15]. 314 Increased biomechanical loading is typically interpreted by both increased cortical 315 bone robusticity and decreased osteon size [55, 69]. If this understanding is applied 316 to the radii, it suggests the thicker cortical bone relates to decreased biomechanical 317 loading indicated by the larger osteons and the lower OPD. 318

Our findings for OPD have significance for studies that estimate age from OPD 319 in forensic and archaeological contexts [54], as well as our current understanding of 320 radius bone biology. Firstly, this analysis reveals insights into age-related OPD 321 asymptote. The asymptote is a point at which new Haversian systems begin to 322 remove evidence of existing Haversian systems $[54,57]$. If it can be assumed that 323 cortical bone develops in the radius in the expected fashion, with size increasing 324 with heavy loading [55, 69], this could lead to the OPD asymptote being reached 325 faster in this bone than in others, based on the relationships established here. The 326 point is reached at different times in different bones as the average asymptote for the 327 rib is $30 / \mathrm{mm}^{2}[58,70]$ but is $50 / \mathrm{mm}^{2}$ for the femur $[58,71]$. The radius may prove 328 to be less reliable for age estimation at an earlier age as the larger osteons could 329 cause the asymptote to be reached earlier, especially in active individuals. As such, 330 the results of the current study suggest the radius may be a less reliable indicator of 331 age compared to other long bones in medieval samples. As with other studies that 332 have examined bone cross-sections, our results were not consistent in every region 333 [61]. Only the octants as a whole and the periosteal sections showed significant cor- 334 relations in all variables. Further research should focus on the impact of the cortical 335 bone dimensions on the formation of Haversian systems and investigate the differ- 336 ences identified between the radius and the femur.

Secondly, this short analysis illustrates new macro- and microscopic bone growth relationships in the medieval human radius, which is a bone of importance when studying osteoporosis-related fractures in the living. Radius is the site of Colles fractures which commonly occur following falls on the forearm by people of fragile bone [59]. Distal radius fractures are routinely used as indicators that a patient may be osteoporotic [72]. A 2001 estimate suggested that annually 71,000 adults (males and females combined) develop a radius fracture in the UK [73]. While radiographic methods are the gold standard of radius assessment in these cases, our understanding of radius bone remodelling remains limited in the living. Our short study suggests that the accumulation of secondary bone tissue within the radius anatomy 
occurs faster than in other bones in medieval humans. Coupled with recent modern evidence that the distal radius fracture is more prevalent in socially deprived patients ( $n=4463$ patients treated at the Leicester Royal Infirmary between 2007 and 2010) [74], our preliminary data invite further research into radius bone histology per SES groups to elucidate the complex cortical radius bone modelling and remodelling relationships.

\subsection{Conclusion}

This chapter focused on the analysis of limb bone microstructure from medieval human remains to propose a SES-related bone quality and quantity development model and demonstrate that medieval human bone samples can be used to expand our current understanding of bone biology of relevance to osteoporosis. We firstly evaluated childhood developmental disturbances recorded in the teeth against bone microstructure density in low and high SES groups from an archaeological site in eleventh to sixteenth centuries Canterbury, UK. We reported that only high SES individuals appear to develop higher adult bone density despite their experiences of development stress in the early years of their ontogeny. Using the same skeletal collection, we then used bone microstructure density in human medieval radius samples to investigate relationships between bone remodelling and entire cross-sectional area. We reported implications for modern and ancient human bone research supplying preliminary data for the human radius suggesting its bone microstructure asymptote may be reached earlier than in other skeletal elements. This second shortly illustrates that medieval human remains, preservation permitting, can make contributions to modern bone biology research.

\section{References}

1. Larsen SC. Bioarchaeology: interpreting behaviour from the human skeleton. Cambridge: University Press; 1997.

2. Miszkiewicz JJ, Mahoney P. Human bone and dental histology in an archaeological context. In: Errickson D, Thompson T, editors. Human remains: another dimension: the application of imaging to the study of human remains. Amsterdam: Elsevier; 2017. p. 29-43.

3. Miszkiewicz JJ, Mahoney P, Miszkiewicz JJ, Mahoney P. Ancient human bone microstructure in medieval England: comparisons between two socio-economic groups. Anat Rec. 2016;299(1):42-59. https://doi.org/10.1002/ar.23285.

4. Pitfield R, Miszkiewicz JJ, Mahoney P. Cortical histomorphometry of the human humerus during ontogeny. Calcif Tissue Int. 2017;101(2):148-58. https://doi.org/10.1007/s00223-017-0268-1.

5. Stout SD, Lueck R. Bone remodeling rates and skeletal maturation in three archaeological skeletal populations. Am J Phys Anthropol. 1995;98(2):161-71. https://doi.org/10.1002/ ajpa.1330980206.

6. Cho H, Stout SD. Age-associated bone loss and intraskeletal variability in the Imperial Romans. J Anthropol Sci. 2011;89:109-25. https://doi.org/10.4436/jass.89007.

7. Mulhern DM, Van Gerven DP. Patterns of femoral bone remodeling dynamics in a medieval Nubian population. Am J Phys Anthropol. 1997;104(1):133-46. https://doi.org/10.1002/ (SICI) 1096-8644(199709)104:1<133::AID-AJPA9>3.0.CO;2-S. 
8. Robling AG, Stout SD. Histomorphology, geometry, and mechanical loading in past popula- 390 tions. In: Agarwal SC, Stout SD, editors. Bone loss and osteoporosis. Boston: Springer; 2003. 391 p. 189-205.

9. Brickley MB, Agarwal SC. Techniques for the investigation of age-related bone loss and osteoporosis in archaeological bone. In: Agarwal SC, Stout SD, editors. Bone loss and osteoporosis. Boston: Springer; 2003. p. 157-72.

10. Miszkiewicz JJ. Linear enamel hypoplasia and age-at-death at Medieval (11th-16th Centuries) St. Gregory's Priory and cemetery, Canterbury, UK. Int J Osteoarchaeol. 2015;25(1):79-87. https://doi.org/10.1002/oa.2265.

11. Goodman AH, Rose JC. Assessment of systemic physiological perturbations from dental enamel hypoplasias and associated histological structures. Am J Phys Anthropol. 1990;33(Suppl 11):59-110. https://doi.org/10.1002/ajpa.1330330506.

12. Robling AG, Castillo AB, Turner $\mathrm{CH}$. Biomechanical and molecular regulation of bone remodeling. Annu Rev Biomed Eng. 2006;8:455-98. https://doi.org/10.1146/annurev. bioeng.8.061505.095721.

13. Masterson EE, Fitzpatrick AL, Enquobahrie DA, Mancl LA, Eisenberg DT, Conde E, Hujoel PP. Dental enamel defects predict adolescent health indicators: a cohort study among the Tsimane' of Bolivia. Am J Hum Biol. 2018;30(3):e23107. https://doi.org/10.1002/ajhb.23107.

14. Renthal NE, Ma NS. Normal bone physiology 101. In: Pitts S, Gordon CM, editors. A practical approach to adolescent bone health. Cham: Springer; 2018. p. 11-25.

15. Miszkiewicz JJ, Mahoney P. Histomorphometry and cortical robusticity of the adult human femur. J Bone Miner Metab. 2018. https://doi.org/10.1007/s00774-017-0899-3.

16. Anderson T, Wakely J, Carter A. Medieval example of metastatic carcinoma: a dry bone, radiological, and SEM study. Am J Phys Anthropol. 1992;89(3):309-23. https://doi.org/10.1002/ ajpa.1330890305.

17. Hicks M, Hicks A. St Gregory's Priory, Northgate, Canterbury: excavations 1988-1991, The archaeology of Canterbury new series volume II. Canterbury: Canterbury Archaeological Trust Limited; 2001.

18. Anderson T, Andrews J. A recently excavated odontome from medieval Canterbury, Kent. Int J Osteoarchaeol. 1993;3(2):99-104. https://doi.org/10.1002/oa.1390030206.

19. Miszkiewicz JJ. Investigating histomorphometric relationships at the human femoral midshaft in a biomechanical context. J Bone Miner Metab. 2016;34(2):179-92. https://doi.org/10.1007/ s00774-015-0652-8.

20. Mahoney P, Miszkiewicz JJ, Pitfield R, Schlecht SH, Deter C, Guatelli-Steinberg D. Biorhythms, deciduous enamel thickness, and primary bone growth: a test of the Havers-Halberg Oscillation hypothesis. J Anat. 2016;228(6):919-28. https://doi.org/10.1111/joa.12450.

21. Mahoney P, Miszkiewicz JJ, Chapple S, Le Luyer M, Schlecht SH, Stewart TJ, Griffiths RA, Deter C, Guatelli-Steinberg D. The biorhythm of human skeletal growth. J Anat. 2018;232(1):26-38. https://doi.org/10.1111/joa.12709.

22. Buikstra JE, Ubelaker DH. Standards for data collection from human skeletal remains, Arkansas archaeological survey research series no. 44. Fayetteville: Arkansas Archeological Survey; 1994.

23. Brent J. Canterbury in the olden time. 2nd ed. London: Simpkin, Marshall \& Company; 1879.

24. Hicks MJ, Anderson T. Excavations: Canterbury sites, 22. St. Gregory's Priory, (A) the cemetery. In: Canterbury's archaeology, 1988 - 1989. Canterbury: Canterbury Archaeological Trust; 1989. p. 15-6.

25. Bayard T. Sweet herbs and sundry flowers: medieval gardens and the gardens of the cloisters. New York: The Metropolitan Museum of Art; 1997.

26. Dyer C. Everyday life in medieval England. 2nd ed. London: Hambledon and London Publishers; 2000.

27. Riancho JA, Brennan-Olsen SL The epigenome at the crossroad between social factors, 440 inflammation, and osteoporosis risk. Clin Rev Bone Miner Metab. 2017;15(2):59-68. https:// 441 doi.org/10.1007/s12018-017-9229-5. 
28. Evans GW, Kantrowitz E. Socioeconomic status and health: the potential role of environmental risk exposure. Annu Rev Public Health. 2002;23(1):303-31. https://doi.org/10.1146/ annurev.publhealth.23.112001.112349.

29. Hillson S, Bond S. Relationship of enamel hypoplasia to the pattern of tooth crown growth: a discussion. Am J Phys Anthropol. 1997;104(1):89-103. https://doi.org/10.1002/ (SICI) 1096-8644(199709)104:1<89::AID-AJPA6>3.0.CO;2-8.

30. Guatelli-Steinberg D. Macroscopic and microscopic analyses of linear enamel hypoplasia in Plio-Pleistocene South African hominins with respect to aspects of enamel development and morphology. Am J Phys Anthropol. 2003;120(4):309-22. https://doi.org/10.1002/ajpa.10148.

31. Goodman AH, Armelagos GJ. The chronological distribution of enamel hypoplasia in human permanent incisor and canine teeth. Arch Oral Biol. 1985;30(6):503-7. https://doi. org/10.1016/0003-9969(85)90097-4.

32. King T, Humphrey LT, Hillson S. Linear enamel hypoplasias as indicators of systemic physiological stress: evidence from two known age-at-death and sex populations from postmedieval London. Am J Phys Anthropol. 2005;128(3):547-59. https://doi.org/10.1002/ajpa.20232.

33. Goodman AH, Martinez C, Chavez A. Nutritional supplementation and the development of linear enamel hypoplasias in children from Tezonteopan, Mexico. Am J Clin Nutr. 1991;53(3):773-81. https://doi.org/10.1093/ajcn/53.3.773.

34. Moggi-Cecchi J, Pacciani E, Pinto-Cisternas J. Enamel hypoplasia and age at weaning in 19thcentury Florence, Italy. Am J Phys Anthropol. 1994;93(3):299-306. https://doi.org/10.1002/ ajpa.1330930303.

35. Neiburger EJ. Enamel hypoplasias: poor indicators of dietary stress. Am J Phys Anthropol. 1990;82(2):231-2. https://doi.org/10.1002/ajpa.1330820211.

36. Blakey ML, Leslie TE, Reidy JP. Frequency and chronological distribution of dental enamel hypoplasia in enslaved African Americans: a test of the weaning hypothesis. Am J Phys Anthropol. 1994;95(4):371-83. https://doi.org/10.1002/ajpa.1330950402.

37. Reitsema LJ, McIlvaine BK. Reconciling "stress" and "health" in physical anthropology: what can bioarchaeologists learn from the other subdisciplines? Am J Phys Anthropol. 2014;155(2):181-5. https://doi.org/10.1002/ajpa.22596.

38. Geber J. Skeletal manifestations of stress in child victims of the Great Irish Famine (18451852): prevalence of enamel hypoplasia, Harris lines, and growth retardation. Am J Phys Anthropol. 2014;155(1):149-61. https://doi.org/10.1002/ajpa.22567.

39. Martin RB. Toward a unifying theory of bone remodeling. Bone. 2000;26(1):1-6. https://doi. org/10.1016/S8756-3282(99)00241-0.

40. Crowder C, Stout S. Bone histology: an anthropological perspective. Florida: CRC Press; 2011.

41. Hassett BR. Evaluating sources of variation in the identification of linear hypoplastic defects of enamel: a new quantified method. J Archaeol Sci. 2012;39(2):560-5. https://doi.org/10.1016/j. jas.2011.10.017.

42. Bartlett R. England under the Norman and Angevin kings 1075 - 1225. Oxford: Clarendon Press: 2000.

43. Tatton-Brown T. The beginnings of St. Gregory's Priory and St. John's Hospital in Canterbury. In: Eales R, Sharpe R, editors. Canterbury and the Norman conquest: churches, saints and scholars 1066-1109. London: Hambledon Continuum; 1995.

44. Bhote T. Medieval feasts and banquets: food, drink, and celebration in the middle ages. New York: The Rosen Publishing Group; 2004.

45. Reitsema LJ, Crews DE, Polcyn M. Preliminary evidence for medieval Polish diet from carbon and nitrogen stable isotopes. J Archaeol Sci. 2010;37(7):1413-23. https://doi.org/10.1016/j. jas.2010.01.001.

46. Collí CM, Sosa TS, Tiesler V, Cucina A. Linear enamel hypoplasia at Xcambó, Yucatán, during the Maya Classic period: an evaluation of coastal marshland impact on ancient human populations. J Comp Hum Biol. 2009;60(4):343-58. https://doi.org/10.1016/j.jchb.2009.04.001.

47. Roberts CA, Manchester K. The archaeology of disease. 3rd ed. Ithaca: Cornell University Press; 2007. 
48. Gosman JH. Growth and development: morphology, mechanisms, and abnormalities. In: 497 Crowder C, Stout S, editors. Histology: an anthropological perspective. Florida: CRC Press; 498 2011. p. 23-44.

49. Miszkiewicz JJ. Histology of a Harris line in a human distal tibia. J Bone Miner Metab. 2015;33(4):462-6. https://doi.org/10.1007/s00774-014-0644-0.

50. Steckel RH. Stature and the standard of living. J Econ Lit. 1995;33(4):1903-40.

51. Evans HL, Ayala AG, Romsdahl MM. Prognostic factors in chondrosarcoma of bone a clinicopathologic analysis with emphasis on histologic grading. Cancer. 1977;40:818-31. https://doi. org/10.1002/1097-0142(197708)40:2<818::AID-CNCR2820400234>3.0.CO;2-B.

52. Hutchison AJ, Whitehouse RW, Boulton HF, Adams JE, Mawer EB, Freemont TJ, Gokal R. Correlation of bone histology with parathyroid hormone, vitamin D3, and radiology in endstage renal disease. Kidney Int. 1993;44(5):1071-7. https://doi.org/10.1038/ki.1993.350.

53. Schultz M. Light microscopic analysis of macerated pathologically changed bones. In: Crowder C, Stout S, editors. Bone histology an anthropological perspective. Boca Raton: CRC Press; 2012. p. 253-96.

54. Robling AG, Stout SD. Histomorphometry of human cortical bone: applications to age estimation. In: Katzenberg MA, Saunders SR, editors. Biological anthropology of the human skeleton. 2nd ed. Hoboken: Wiley; 2008. p. 149-82.

55. Van Oers RFM, Ruimerman R, Tanck E, Hilbers PA, Huiskes R. A unified theory for osteonal and hemi-osteonal remodelling. Bone. 2008;42(2):250-9. https://doi.org/10.1016/j. bone.2007.10.009.

56. Britz HM, Thomas CD, Clement JG, Cooper DM. The relation of femoral osteon geometry to age, sex, height, and weight. Bone. 2009;45(1):77-83. https://doi.org/10.1016/j. bone.2009.03.654

57. Goliath JR. Variation in osteon circularity and its impact on estimating age at death [Master's thesis]. Ohio State University; 2010.

58. Stout S, Crowder C. Bone remodeling histomorphology and histomorphometry. In: Crowder $\mathrm{C}$, Stout S, editors. Bone histology an anthropological perspective. Boca Raton: CRC Press; 2012. p. 1-22.

59. Hosseini HS, Dünki A, Fabech J, Stauber M, Vilayphiou N, Pahr D, Pretterklieber M, Wandel J, van Rietbergen B, Zysset PK. Fast estimation of Colles' fracture load of the distal section of the radius by homogenized finite element analysis based on HR-pQCT. Bone. 2017;97:65-75. https://doi.org/10.1016/j.bone.2017.01.003.

60. Gocha TP, Agnew AM. Spatial variation in osteon population density at the human femoral midshaft: histomorphometric adaptations to habitual load environment. J Anat. 2016;228(5):73345. https://doi.org/10.1111/joa.12433.

61. Fahy GE, Deter C, Pitfield R, Miszkiewicz JJ, Mahoney P. Bone deep: variation in stable isotope ratios and histomorphometric measurements of bone remodelling within adult humans. $\mathrm{J}$ Archaeol Sci. 2017;87:10-6. https://doi.org/10.1016/j.jas.2017.09.009.

62. Goldman HM, Bromage TG, Thomas CD, Clement JG. Preferred collagen fiber orientation in the human mid-shaft femur. Anat Rec A Discov Mol Cell Evol Biol. 2003;272(1):434-45. https://doi.org/10.1002/ar.a.10055.

63. Goldman HM, Bromage TG, Boyde A, Thomas CD, Clement JG. Intrapopulation variability in mineralization density at the human femoral mid-shaft. J Anat. 2003;203(2):243-55.

64. Goldman HM, Thomas CD, Clement JG, Bromage TG. Relationship among microstructural properties of bone at the human midshaft femur. J Anat. 2005;206(2):127-39. https://doi. org/10.1111/j.1469-7580.2005.00385.x.

65. Thomas CDL, Feik SA, Clement JG. Regional variation of intracortical porosity in the midshaft of the human femur and tibia. J Anat. 2005;206(2):115-25. https://doi. org/10.1111/j.1469-7580.2005.00384.x.

66. McFarlin SC, Terranova CJ, Zihlman AL, Enlow DH, Bromage TG. Regional variability in secondary remodeling within long bone cortices of catarrhine primates: the influence of bone growth history. J Anat. 2008;213(3):308-24. https://doi.org/10.1111/j.1469-7580.2008.00947.x. 
67. Caccia G, Magli F, Tagi VM, Porta DGA, Cummaudo M, Marquez-Grant N, Cattaneo C. Histological determination of the human origin from dry bone: a cautionary note for subadults. Int J Legal Med. 2016;130(1):299-307. https://doi.org/10.1007/s00414-015-1271-6.

68. Dempster DW, Compston JE, Drezner MK, Glorieux FH, Kanis JA, Malluche H, Meunier PJ, Ott SM, Recker RR, Parfitt AM. Standardized nomenclature, symbols, and units for bone histomorphometry: a 2012 update of the report of the ASBMR histomorphometry nomenclature committee. J Bone Miner Res. 2013;28(1):2-17. https://doi.org/10.1002/jbmr.1805.

69. Van Oers RFM, Ruimerman R, van Rietbergen B, Hilbers PAJ, Huiskes R. Relating osteon diameter to strain. Bone. 2008;43(3):476-82. https://doi.org/10.1016/j.bone.2008.05.015.

70. Stout S, Paine R. Bone remodeling rates: a test on an algorithm for estimating missing osteons. Am J Phys Anthropol. 1994;93(1):123-9. https://doi.org/10.1002/ajpa.1330930109.

71. Frost HM. Secondary osteon population densities: an algorithm for estimating the missing osteons. Am J Phys Anthropol. 1987;30(S8):239-54. https://doi.org/10.1002/ ajpa.1330300513.

72. Jantzen C, Cieslak LK, Barzanji AF, Johansen PB, Rasmussen SW, Schmidt TA. Colles' fractures and osteoporosis - a new role for the Emergency Department. Injury. 2016;47(4):930-3. https://doi.org/10.1016/j.injury.2015.11.029.

73. O'neill TW, Cooper C, Finn JD, Lunt M, Purdie D, Reid DM, Rowe R, Woolf AD, Wallace WA. Incidence of distal forearm fracture in British men and women. Osteoporos Int. 2001;12(7):555-8.

74. Johnson NA, Jeffery J, Stirling E, Thompson J, Dias JJ. Effects of deprivation, ethnicity, gender and age on distal radius fracture incidence and surgical intervention rate. Bone. 2018;121:1-8. https://doi.org/10.1016/j.bone.2018.12.018. 